\title{
ANTIOXIDANT ACTIVITY OF THE INFLORESCENTS OF VERNONIA CALVOANA GROWING IN YAKURR LOCAL GOVERNMENT AREA OF CROSS RIVER STATE, NIGERIA
}

\author{
GODWIN ENEJI EGBUNG, ITEM JUSTIN ATANGWHO, ZINADUM B. KIASIRA, IWARA ARIKPO IWARA AND \\ GODWIN OJU IGILE
}

(Received 10 June 2016; Revision Accepted 12 August 2016)

\begin{abstract}
Vernonia calvoana is an indigenous green leafy vegetable that grows around the Cameroons and the southern part of Nigeria. This study was designed to evaluate the phytochemical and antioxidant activity of $V$. calvoana inflorescents using the following methods: 1, 1 - diphenyl-2-picrylhydrazyl radical (DPPH), Ferric reducing/antioxidant power (FRAP), 2, 2-azobis-3-ethyl benzothiolin-6-sulphonic acid (ABTS), anti-lipid, superoxide, phosphomolybdate and ascorbic acid assay. The result showed significantly high saponins, alkaloids and polyphenols at $(p<0.05)$. Oxalates, cyanates, phytates, tannins, terpenoids, steroids, anthraquinones, flavonoids and sesquiterpene lactones were found in trace amounts. The assay indicated strong free radical scavenging activity, including ABTS, anti-lipid, superoxide, phosphomolybdate activities of the inflorescents. However, the percentage antioxidant capacity was low in the inflorescents using FRAP, whereas the antioxidant capacity increased with increase in concentration compared to the ascorbic acid standard. Moreover, the inflorescents were found to show stronger antioxidant activity $(137.0 \pm 6.86)$ compared to ascorbic acid (79.44\%).We therefore conclude that $V$. calvoana inflorescents could serve as source strong diatary antioxidants.
\end{abstract}

RUNNING TITLE: Vernonia calvoana inflorescents in Calabar

KEYWORDS: Vernonia calvoana, antioxidant activity and nutraceuticals

\section{INTRODUCTION}

Vernonia colvoana Hook $\mathrm{F}$. is one of the green leafy vegetables consumed by inhabitants of the Cameroons and Nigeria where the plant grows. It is commonly known as the African sweet bitter leaf due to its non bitter taste (Mensor, 2001 and Fidelia 2000). Although being an edible vegetable, its inflorescents are not widely consumed except among the natives of the Northern Senatorial district of Cross River State, Nigeria, where the inflorescent is prepared as a soup delicacy and consumed. The inflorescents of Vernonia calvoana to our knowledge, there is no scientific information or documentation that has been carried out. Plant rich foods are sources of natural antioxidants, dietary antioxidants are known to reduce the risk for chronic diseases including cancer, and heart disease. Primary sources of natural occurring antioxidants are whole grains, fruits and vegetables. Plant sourced food antioxidants like vitamin C, vitamin E, Beta-carotene and phenolic acids have been recognized as having the potential to reduce disease risk (Baskar, 2007). Most of the antioxidant compounds in tropical diets are derived from plant sources and belong to various classes of compounds with a wide variety of physical and chemical properties.

Vernonia calvoana - a leafy vegetable has rich nutritive value and antioxidant activity (Igile et al., 2013). In spite of the consumption of the leaf for culinary and claimed ethnobotanical roles such as prevention of oxidative stress and scavenging of free radicals as well as hypolipidemic activity (Iwara et al.,2015). The free radical scavenging action is usually attributed to secondary metabolites that can inhibit or slow down the oxidant of an oxidizable substrate in a chain reaction in human system, hence relevant in the prevention of many diseases (Halliwell et al., 1995). Plants containing secondary compounds such as phenolics and flavonoids

Godwin Eneji Egbung, Department of Biochemistry, University of Calabar, P.M.B. 1115, Calabar, Cross River State, Nigeria.

Item Justin Atangwho, Department of Biochemistry, University of Calabar, P.M.B. 1115, Calabar, Cross River State, Nigeria.

Zinadum B. Kiasira, Department of Biochemistry, University of Calabar, P.M.B. 1115, Calabar, Cross River State, Nigeria.

Iwara Arikpo Iwara, Department of Biochemistry, University of Calabar, P.M.B. 1115, Calabar, Cross River State, Nigeria.

Godwin Oju Igile, Department of Biochemistry, University of Calabar, P.M.B. 1115, Calabar, Cross River State, Nigeria. 
have the capacity to scavenge free radicals (Benabadji, 2004). A small indigenous people (Bekwarra) of Northern Cross River State, Nigeria, consume the inflorescents of Vernonia calvoana as a delicacy, yet to our knowledge, there is no documented information on the nutritional and health benefits of the inflorescents. Consequently, the present study evaluated the phytochemical and antioxidant properties of Vernonia calvoana inflorescents.

\section{MATERIALS AND METHODS}

Collection of plant material: The inflorescent of Vernonia calvoana was purchased in the month of October, 2014 from a local farmer in Asiga, Yakurr Local Government Area of Cross River State, Nigeria. It was transported to University of Calabar. The botanical authentication was carried out by a botanist, Pastor Frank Apojoye who assigned a voucher number BOT/2014/VCi/001. The inflorescents were washed with clean tap water and allowed to drain at the Department of Biochemistry. Thereafter it was shade-dried for fourteen days. The shade dried sample was ground using an electric stainless steel mill at the Department of Chemistry, University of Calabar. The ground sample was stored in an air tight plastic container and kept in the refrigerator at $4^{\circ} \mathrm{C}$ till required for analysis. The portion for the antioxidant assay was pretreated with acetic acid to allow for extraction of the active antioxidant compounds in the materials. The acetic acid suspension was filtered with Whatman No.1 Filter paper and the filtrate used for the antioxidant assay.

\section{The 1,1-diphenyl-2-picrylhydrazyl radical (DPPH)} spectrophotometric assay:

The 1,1-diphenyl-2-picrylhydrazyl radical (DPPH) spectrophotometric assay was determined using the methods of Mensor et al. (2001). 20ml of test extract at a graded concentration of $1.0,0.5,0.25,0.125$, $0.0625 \mu \mathrm{g} / \mathrm{ml}$ were mixed with $1 \mathrm{ml}$ of $0.5 \mathrm{mM} \mathrm{DPPH}$ (in methanol) on a 96-well plate and incubated for 30 minutes at room temperature. The reaction well were measured in triplicate. The absorbance was taken at $517 \mathrm{~nm}$ with a microplate reader. The percentage of radical scavenging activity (RSA) was calculated as follows:

$\% \mathrm{RSA}=$ Absorbance of control-Absorbance of sample $\times 100$ Absorbance of control 1

\section{The Ferric reducing/antioxidant power (FRAP) assay:}

The Ferric reducing/antioxidant power (FRAP) assay was determined using the methods of Benzie and Strain (1999). The principle is based on the reduction of the ferric-tripyridyltriazine compound to its ferrous coloured form in the presence of antioxidant. The FRAP reagent contained $2.5 \mathrm{ml}$ of $10 \mathrm{mM} \mathrm{2,4,6-tripyridyltriazine} \mathrm{solution}$ in $40 \mathrm{mM} \mathrm{HCl}$ and $2.5 \mathrm{ml}$ of $20 \mathrm{mM} \mathrm{FeCl}_{3}$ and $25 \mathrm{ml}$ of $0.3 \mathrm{M}$ acetate buffer, $\mathrm{pH} 3.6$, and was prepared freshly and pre-warmed at $37^{\circ} \mathrm{C}$. Aliquot of $40 \mathrm{ml}$ of the extracts were mixed with $0.2 \mathrm{ml}$ of distilled water and $1.8 \mathrm{ml}$ of FRAP reagents. The absorbance of the reaction mixture at $593 \mathrm{~nm}$ was measured spectro photometrically after incubation at $37^{\circ} \mathrm{C}$. The assay was performed in triplicate and there was formation of a blue coloured $\mathrm{Fe}^{2+}$ tripyridyltriazine compound from colourless oxidized $\mathrm{Fe}^{3+}$ formed by the action of electron donating antioxidant.

\section{2,2-azobis-3-ethyl benzothiozoline-6-sulphonic acid (ABTS) assay:}

2,2-azobis-3-ethyl benzothiozoline-6-sulphonic acid (ABTS) radical cation scavenging activity was estimated using the method of Re et al. (1999) with some slight modifications. About $7 \mathrm{ml}$ of 2,2-azobis-3-ethyl benzothiozoline-6-sulphonic acid (ABTS) solution was reacted with $2.45 \mathrm{mM}$ potassium persulfate and kept overnight in the dark for generation of dark coloured ABTS radicals. The absorbance was adjusted to 0.7 at $745 \mathrm{~nm}$ by dilution with addition of a few drops of the ABTS solution into $30 \mathrm{ml}$ of phosphate Buffered saline (PBS, pH 7.4). 10 microlitres of the sample solution at a graded concentration $(0.125,0.25,0.5,1.0$ or $2.0 \mu \mathrm{g} / \mathrm{ml})$ in methanol was mixed with $2 \mathrm{ml}$ ABTS solution, and the absorbance was measured at $745 \mathrm{~nm}$ after $6 \mathrm{~min}$. The assay was performed in triplicate.

Percent inhibition was calculated by the formula: $\%$ ABTS scavenging effect $=$

$$
\text { (control absorbance-Fraction abs) } \times 100
$$

Control absorbance

\section{Anti-lipid peroxidation assay:}

Anti-lipid peroxidation assay was carried out according to the methods described previously by Dorman et al. (2003). An aliquot of egg yolk (10\%, w/v) was prepared in potassium chloride $(1.15 \%, w / v)$. The yolk was lyophilized for $30 \mathrm{sec}$ and centrifuged for $15 \mathrm{~min}$ at 3000rpm. The solutions were pipette into a flasks and volume was made up to $1 \mathrm{ml}$ with distilled water. The determination were done in triplicate, n-butanol was added to the mixture. It was vortexed and incubated for $60 \mathrm{~min}$ in water bath. Thereafter, it was stirred and centrifuged for $10 \mathrm{~min}$ at 3000rpm. Absorbance was taken at $532 \mathrm{~nm}$. Butylated hydroxytoluene served as standard.The percent antilipid peroxidation was determined by the formula $(1-\mathrm{s} / \mathrm{c}) \times 100$ where, $\mathrm{c}=$ Absorbance of control and $\mathrm{s},=$ Absorbance of test fraction.

\section{Superoxide anion radical scavenging assay:}

Superoxide anion radical scavenging assay was estimated using the method of Nishikimi (1972) with some minor modifications. $1 \mathrm{ml}$ of the extract was added to $0.5 \mathrm{ml}$ of phosphate buffer $(50 \mathrm{mM}, \mathrm{pH} 7.4)$ and $0.3 \mathrm{ml}$ of $50 \mathrm{mM}$ riboflavin and incubated for $20 \mathrm{~min}$ at $50^{\circ} \mathrm{C}$. Afterward $2.5 \mathrm{ml}$ of distilled water plus $0.5 \mathrm{ml}$ of phosphate buffer were mixed and the absorbance was recorded at $560 \mathrm{~nm}$. The percent inhibition of superoxide anion was calculated as follows:

$\%$ scavenging activity $=\left(\frac{1-\text { absorbance of fraction }}{(\text { Absorbance of control })}\right) 100$ (Absorbance of control) 


\section{Total antioxidant capacity assay:}

Total antioxidant capacity (phosphomolybdate assay) was carried out using the methods described by Umamaheswari and Chatterjee (2008). An aliquot of $0.1 \mathrm{ml}$ of varying concentrations $(10,50,100,200,400$, 600 and $800 \mu \mathrm{g} / \mathrm{ml}$ ) of sample was added to $1 \mathrm{ml}$ of reagent $\left(0.6 \mathrm{MH}_{2} \mathrm{SO}_{4}, 0.028 \mathrm{M}\right.$ sodium phosphate $0.004 \mathrm{M}$ ammonium phosphomolybdate) and incubated for $90 \mathrm{~min}$ at $90^{\circ} \mathrm{C}$ in a water bath. Thereafter, it was allowed to cool and its absorbance was read at $765 \mathrm{~nm}$ after the samples cooled to room temperature. Ascorbic acid serves as standard. The total antioxidant capacity was calculated as follows:

Absorbance of control - absorbance of sample $\times 100$ Absorbance of control

\section{Phytochemical assay:}

The quantitative determination of fourteen phytochemicals was carried out using the standard methods of Rizwan et al., 2011, Edeoga et al., 2005, Gestener et al., 1971, Van-Burden, 1981 and Harborne, 1973).

Data obtained from the in vitro antioxidant assay and phytochemical analyses are presented as mean \pm standard deviation.

\section{RESULTS}

The results for the quantitative phytochemical screening is presented in table 1 while that of antioxidant activity of the inflorescent of Vernonia calvoana are presented in tables 2 to 5

Table 1: Results of phytochemical evaluation of Vernonia calvoana inflorescents

\begin{tabular}{lll}
\hline & Phytochemicals & $\mathbf{m g} / \mathbf{1 0 0 g}$ \\
\hline 1 & Oxalates $(\mathrm{mg} / 100 \mathrm{~g})$ & $0.380 \pm 0.042$ \\
2. & Cyanate $(\mathrm{mg} / 100 \mathrm{~g})$ & $0.026 \pm 0.006$ \\
3. & Phytate $(\mathrm{mg} / 100 \mathrm{~g})$ & $0.419 \pm 0.067$ \\
4. & Alkaloids $(\mathrm{mg} / 100 \mathrm{~g})$ & $5.0 \pm 0.124$ \\
5. & Tannins $(\mathrm{mg} / 100 \mathrm{~g})$ & $0.046 \pm 0.005$ \\
6. & Saponins $(\%)$ & $7.82 \pm 0.58$ \\
7. & Terpenoids $(\mathrm{mg} / 100 \mathrm{~g})$ & $0.477 \pm 0.58$ \\
8. & Phlobatannins $(\mathrm{mg} / 100 \mathrm{~g})$ & - \\
9. & Polyphenol $(\mathrm{mg}$ gallic acid $/ \mathrm{g}$ weight of extract) & $2.77 \pm 0.519$ \\
10. & Steroids $(\mathrm{mg} / 100 \mathrm{~g})$ & $0.155 \pm 0.015$ \\
11. & Glycosides $(\mathrm{mg} / 100 \mathrm{~g})$ & - \\
12. & Anthraquinones $(\mathrm{mg} / 100 \mathrm{~g})$ & $0.02 \pm 0.003$ \\
13. & Flavonoids $(\mathrm{mg} \mathrm{quarcetin} / \mathrm{g}$ weight of extract) & $0.9 \pm 0.235$ \\
14. & Sesquiterpene lactone $(\mathrm{mg} / 100 \mathrm{~g})$ & $0.4 \pm 0.002$ \\
\hline
\end{tabular}

Values are expressed as mean $\pm S D$, determinations were done in triplicates.

The percentage composition of steroids, anthraquinones, cyanates and tannins were present in trace amounts while cyanogenic glycosides and phlobatannins were not detected. Saponins, alkaloids and flavonoids were found in large amount relative to other phytochemicals.

From table 2 below, the result showed that at a concentration of 50 the antioxidant capacity was
$18.12 \%$, while at a minimal concentration of 10 , the antioxidant capacity was $12.36 \%$ and at maximum concentration of 800 showed an antioxidant value of $51.87 \%$ for Vernonia calvoana inflorescents. At $100 \mu \mathrm{g} / \mathrm{ml}$, the $\%$ antioxidant activity of the inflorescence revealed $25.41 \%$ while at $200 \mu \mathrm{g} / \mathrm{ml}$, there was a $\%$ antioxidant activity of 30.78 .

Table 2: The percentage antioxidant in Vernonia calvoana inflorescence using DPPH

\begin{tabular}{ll}
\hline Concentration $(\boldsymbol{\mu g} / \mathbf{m l})$ & \% antioxidant \\
\hline 10 & 12.36 \\
50 & 18.12 \\
100 & 25.41 \\
200 & 30.78 \\
400 & 37.36 \\
600 & 48.11 \\
800 & 51.87 \\
\hline
\end{tabular}

From table 3 below, the result indicated that at a high concentration of 800 the antioxidant capacity is
$79.44 \%$, while at a low concentration of 10 the antioxidant capacity was $60.17 \%$. 
Table 3: The percentage antioxidant capacity in Vernonia calvoana inflorescence using ascorbic acid assay

\begin{tabular}{ll}
\hline Concentration $(\boldsymbol{\mu g} / \mathbf{m l})$ & $\%$ antioxidant capacity \\
\hline 10 & 60.17 \\
50 & 71.33 \\
100 & 73.81 \\
200 & 75.58 \\
400 & 77.16 \\
600 & 77.77 \\
800 & 79.44 \\
\hline
\end{tabular}

From table 4 below, the result revealed that increase in concentration result to increase in FRAP value, at concentration of 10 the FRAP value was
$0.249 \mathrm{mM}$ and at 50 it is $0.301 \mathrm{mM}$, at 800 concentration, FRAP was $1.223 \mathrm{mM}$.

Table 4: The concentration of Vernonia calvoana inflorescents using FRAP

\begin{tabular}{ll}
\hline Concentration $(\mu \mathbf{g} / \mathbf{m l})$ & FRAP $(\mathbf{m M})$ \\
\hline 10 & 0.249 \\
50 & 0.301 \\
100 & 0.365 \\
200 & 0.671 \\
400 & 0.868 \\
600 & 1.138 \\
800 & 1.223 \\
\hline
\end{tabular}

From the table below, ABTS showed a high antioxidant $(137.0 \pm 6.86)$ in the Vernonia calvoana inflorescence when compared with the standard $(51.20 \pm 0.06)$, the antilipid capacity indicate $(112.90 \pm 4.44)$ while superoxide anion radical scavenging $(87.42 \pm 10.60)$.

Table 5: Different antioxidant assays

\begin{tabular}{lll}
\hline Activity & $\begin{array}{l}\mathbf{I C}_{50}(\boldsymbol{\mu g} / \mathbf{m l}) \\
\text { Sample }\end{array}$ & Standard \\
\hline ABTS & $137.0 \pm 6.86$ & $51.20 \pm 0.06$ \\
Antilipid & $112.90 \pm 4.44$ & $34.47 \pm 0.12$ \\
Phosphomolybdate & $3.18 \pm 0.03$ & $1.95 \pm 0.41$ \\
Superoxide & $87.42 \pm 10.60$ & $37.32 \pm 0.07$ \\
\hline
\end{tabular}

Values are expressed as mean $\pm S . D(N=3)$, where determination were in triplicates.

\section{DISCUSSION}

Vernonia calvoana is commonly used as a green edible vegetable and traditionally to treat many diseases whose pathogeneses are, among other factors, linked to oxidative stress. However, information on the antioxidant potentials of the inflorescence that could be relevant in the treatment of such diseases has not been fully documented in literature despite the folk loric claims. The present study documents the preliminary findings on the antioxidant capacity and phytochemicals of Vernonia calvoana inflorescence.

Phytochemicals and antioxidant are currently receiving attention because of striking findings regarding their biological activities (Cho et al., 2003). The alkaloids, saponins and polyphenols present in high concentration in the Vernonia calvoana inflorescence could be responsible for the observed antioxidant activity in the plant. The high phenolics content of any plant usually correlates its antioxidant potentials (Odabasoglu et al., 2004).

The use of FRAP and DPPH, a relatively stable radical is based on the measurement of the scavenging ability of the antioxidant (Baskar et al., 2007). Many phenols and saponins found in vegetable plants have antioxidant capacities that are much stronger than those of vitamin C and E. Flavonols and flavones are flavonoids of particular importance that possess high antioxidant which react with oxygen radical such as hydroxyl radical (Husain et al., 1987). Vernonia calvoana inflorescence showed high antioxidant value $(79.44 \mu \mathrm{g} / \mathrm{ml})$ which correspond to ascorbic acid. This agrees in part with the report of Igile et al. (1995) which indicated that Vernonia amygdalina is a high source of antioxidant $(60.0 \mathrm{mg} / \mathrm{g})$ and nutritive value. Given that the two plants are of the same genus, there is bound to be similarity of some chemical compounds responsible for the antioxidant activity. 
The $I_{50}(\mu \mathrm{g} / \mathrm{ml})(137.0 \pm 6.86)$ of Vernonia calvoana inflorescence is higher compared with $\mathrm{IC}_{50}$ of Vernonia amygdalina $(79.92 \pm 0.042)$. This is an indication that Vernonia calvoana inflorescence may be most beneficial when used as functional food. Antioxidants aid in reducing free radical damage and confer antiageing effects on animals. It could be natural or synthetic, naturally occurring antioxidants includes retinoid (vitamin A), bioflavonoids (citrin), polyphenols (hydroxytyrosol), tocopherol (vitamin E) and ascorbic acid (vitamin C) (Wolf, 2003). Synthetic antioxidant includes butylated hydroxytoluene (BHT), butylated hydroxyanisol (BHA) and propylgallate. The use of these common synthetic alternatives has increasingly raised concerns in the treatment of human diseases due to their side effects (Williams et al., 1999). Hence the need to encourage the use of natural antioxidants and Vernonia calvoana inflorescence comes as a potential rescue.

Vernonia calvoana inflorescence consumed as a local delicacy by the natives of some select ethnic groups in Cross River State has probable potential to reduce oxidative conditions due to its natural antioxidant capacity. Its relatively low concentrations in oxalates, tannins, Cyanides and phytates confer on it the ability to aid in absorption of minerals such as calcium and phosphorus.

\section{CONCLUSION}

Considering the results obtained from our findings, we therefore conclude that Vernonia calvoana inflorescents possess high antioxidant activity with little/ low anti-nutrient contents hence should be promoted as a delicacy in soups served at homes and restaurants and should be exploited as potential candidate for nutraceuticals.

\section{REFERENCES}

Baskar, R., Rajeswari, V and Sathish, T., 2007. In vitro antioxidant studies in leaves of Annona species. Indian Journal Experimental Biology, 45, 480485.

Benabadji, S. H., Wen, R and Yuan, S. G., 2004. Anticarcinogenic and antioxidant activities of diindolylmethane derivates. Acta Pharmacology Sin, 25, 666-671.

Benzie, F. F and Strain, Z. J., 1999. Ferric reducing antioxidant power assay: Direct Measure of total antioxidant activity of biological fluids and modified version for simultaneous measurement of total antioxidant power and ascorbic acid concentration. Methods in enzymology, 299, 1523.

Cho, E. J., Yokozawa, D. Y., Rhyu, S. C., Kim, N., Shibahara, J. C and Park., 2003. Study on the inhibitory effects of Korea medicinal plants and their main compounds on 1,1-diphenyl-2-picrylhydrazyl radical. Phytomedicine, 10, 544-551.
Dorman, H. J. D., Korsar, M., Kahlos, K., Holm, Y and Hiltunen, R., 2003. Antioxidant properties and composition of aqueous extracts from mentha species, hybrids, varieties and cultivars. Journal of Agricultural Food Chemistry, 51, 4563-4569.

Edeoga, H. O., Okwu, D. E and Baebie, B. O., 2005. Phytochemical constituents of some Nigerians Medicinal Plants. African Journals of Biotechnology, 4, (7): 685-688.

Fidelia, U. F., 2000. Morphological variation and effects of processing on edible Vernonia. Students dissertation. Dschang University, Menoua, Cameroon.

Gestetner, B., Assa, Y., Henis, Y., Birk, Y and Bondi, A., 1971. Lucerne saponins. IV. Relationship between their chemical constituent, and haemolytic and antifungal activities. Journal of Scientific Food and Agriculture, 22, 166-172.

Halliwell, B., Aeschbach, R and Loliger, J., 1995. The characterization of antioxidants. Food Chemistry and Toxicology, 33, 601-617.

Harborne, J. B., 1973. Phytochemical methods, London Chapman and Hall, Ltd. Pp.9-188.

Huang, Y., Ding, Z. H and Liu, J. K., 2003. A new highly oxygenated flavone from Vernonia saligna. $Z$. Natureforsch, 58, 347-350.

Husain, S. R., Gillard, J and Cillard, P., 1987. Hydroxyl radical scavenging activity of flavonoids. Phytochemistry, 26, 2489-2491.

Igile, G. O., Iwara, I. A., Mgbeje, B. I. A., Uboh, F. E and Ebong, P. E., 2013. Phytochemical, proximate and nutrient composition of Vernonia calvoana (Asteraceae): A green leafy vegetable in Nigeria. Journal of Food Research, 2, (6): 1.

Igile, G. O., Olesezk, W., Burda, S and Jurzysta, M., 1995. Nutritional assessment of Vernonia amygdalina leaves in growing mice. Journal of Agricultural Food Chemistry, 43, 2162-2166.

Iwara, I. A., Igile, G. O., Uboh, F. E., Eyong, E. U and Ebong, P. E., 2015. Hypoglycemic and hypolipidemic potentials of extract of Vernonia calvoana on alloxan-induced diabetic albino wistar rats. European journal of medicinal Plants 8, (2): 7886.

Mensor, L. L., Menezes, F. S., Leitao, G. G and Reis, T. C., 2001. Screening of Brazilian plant extracts for antioxidant activity by the use of DPPH free radical method. Phytotherapia Research, 15, 127-130.

Nishikimi, M., Rao, N. A and Yagi, K., 1972. The occurrence of superoxide anion in the reaction of reduced phena zinc methosulfate and 
molecular oxygen. Biochemistry of Biophysiology Research and commun, 46, 849854.

Odabasoglu, F., Aslan, A., Cakir, A and Suleyman, H., 2004. Comparison of antioxidant activity and phenolic content of three lichen species. Phytotherapia and Research, 18, 938-941.

Re, R., Pellegrini, N., Proteggente, A., Pannala, A., Yang, M and Rice-Evans, C., 1999. Antioxidant activity applying an improved ABTS radical cation decolorisation assay. Free Radical of Biology \& Medicine, 26, 1231-1237.

Rizwan, A., Kushagra, N., Teskeshwar, K., Mukesh, S and Dhansay, D., 2011. Phytochemical estimation of anthraquinones from cassia species. International Journal of Research in Ayurveda and Pharmacy, 2, (4): 1320-1323.
Umamaheswari, $\mathrm{M}$ and Chatterjee, T., 2008. In vitro antioxidant activities of the fractions of Coccinia grandis L. Leaf extract. African Journal of Traditional Communication Alternative of Medicine, 5, 61-73.

Van-Burden, T. P and Robinson, W. C., 1981. Formation of complexes between protein and Tannin acid. Journal of Agricultural Food and Chemistry, 1, 77-79.

Williams, T., 1999. Food and chemical toxicology, 37, 910.

Wolf, K., Wu, X and Liu, R. H., 2003. Antioxidant activity of apple peels. Journal of Agricultural Food and Chemistry, 51, 609-614. 